\title{
Teachers' Perspective towards Digital Teaching Tools in Thai EFL Classrooms
}

\author{
Raksamon Yordming
}

\begin{abstract}
The purpose of this research was to study of needs of including the Internet in teaching and Internet access of school, teachers' confidence to use digital media in the classroom, administrative support for use of technology in classroom, and types of digital educational tools using in EFL classroom. This research was semi-structured interview and the interview protocol was examined by relevant experts. The subjects of interest were five English language teachers working in Angthong and Phra Nakhon Si Ayutthaya Primary Educational Service Area Office by purposive sampling. Findings of the study suggested that all of participants needed to use the Internet in classroom, felt confident about digital media using in the classroom, the teachers generally felt that their school administrators encouraged technology use, and the participants' general digital technology using were laptop, computer, smart board, MS PowerPoint, and the Internet. On the other hand, some schools did not provide sufficient access to the Internet.
\end{abstract}

Index Terms-Teachers perspective, digital teaching tools, EFL, Thai EFL classrooms.

\section{INTRODUCTION}

In the digital age, information and communication technology (ICT) plays a key role in creating and exchanging knowledge and information around the globe. ICT affects the everyday lives of citizens in many areas - at school, in the workplace and in the community. Knowledge about, access to and the ability to use ICT are vital for effective participation in an information society. ICT is transforming the nature of how work is conducted and the meaning of social relationships. Decentralised decision making, information sharing, teamwork and innovation are key in today's enterprises. Countries wanting to adequately prepare young people for the challenges and opportunities of a globalised economy need to make long term, incremental changes in their education systems to adapt to these new demands. Acquiring and mastering ICT competencies has thus become a major component of education today [1].

However, [2] claimed that many people are afraid of new technology, and, with the increasing presence of the Internet and computers. In education, technology in language teaching is now new. Indeed, technology has been around in language teaching for decades - one might argue for centuries, if we

Manuscript received December 5, 2016; revised June 17, 2017. This work was supported in part by Phranakhon Si Ayutthaya Rajabhat University.

Raksamon Yordming is with Faculty of Education, Phranakhon Si Ayutthaya Rajabhat University, Phranakhon Si Ayutthaya, Thailand (e-mail: mon_spice@hotmail.com). classify the blackboard as a form of technology. Tape recorders, language laboratories and video have been in use since the 1960s and 1970s, and are still used in classrooms around the world [2].

One of the factors that determine educational development and innovation in general is teachers as they are the ones to use the ICT investments for educational development. Technology does not have an educational value in itself. It becomes important when teachers use it in learning-teaching process [3].

The new era assigns new challenges and duties on the modern teacher. The traditional of English teaching has been drastically changed with the remarkable entry of technology. Technology provides so many options as making teaching interesting and also making teaching more productive in terms of improvements. Technology is utilized for the upliftment of modern styles; it satisfies both visual and auditory senses of the students [4].

In the $21^{\text {st }}$ century, technology in English language teaching has increased in popularity. [4] suggested that with the rapid development of science and technology, the emerging and developing of multimedia technology and its application to teaching, featuring audio, visual, animation effects comes into full play in English class teaching and sets a favorable platform for reform and exploration on English teaching model in the new era.

My research extend research on educational digital technology initiatives by focusing on teachers' confidence to use digital media in the classroom, administrative support for use of technology in classroom, the Internet access and using and types of digital educational tools using in EFL classroom.

\section{OBJectives OF THE STUDY}

This research aimed to study of needs of including the Internet in teaching and Internet access of school, teachers' confidence to use digital media in the classroom, and administrative support for use of technology in classroom.

Likewise, the study what do Thai EFL teachers use in their classroom and types of digital educational tools.

\section{METHOD}

This research was semi-structured interview, following the protocol shown in Appendix but also flexible and adaptive to gather data on the most interesting concepts introduced by the participants themselves.

The research interview protocol was examined by relevant experts. 


\section{THE PARTICIPANTS}

The population of interest was English language teachers working in Angthong and Phranakhon Si Ayutthaya Primary Educational Service Area Office; therefore, purposive sampling was employed in order to target the individuals from whom the most relevant information could be obtained. In this study, the researcher believed that focusing on a small group /of participants would be the most effective means of gaining detailed information concerning their views on digital teaching tools. The participants contacted, five teachers agreed to participate; both males and females were included. All of the participants were teaching in a public elementary school. The interview participants are shown in Table I below.

TABLE I: THE INTERVIEW PARTICIPANTS

\begin{tabular}{llll}
\hline \hline No. & Age & $\begin{array}{l}\text { College of } \\
\text { enrollment }\end{array}$ & $\begin{array}{l}\text { Years of English teaching } \\
\text { experience }\end{array}$ \\
\hline 1 & 38 & TEFL & 11 \\
2 & Not specified & Education & 6 \\
3 & 29 & Education & Not specified \\
4 & 45 & Education & 24 \\
5 & 55 & Education & 30 \\
\hline \hline
\end{tabular}

\section{RESUlTS AND DisCUSSIONS}

The results of this study included thoughts on needs of including the Internet in teaching and Internet access of school, teachers' confidence to use digital media in the classroom, and administrative support for use of technology in classroom, and types of digital educational tool.

\section{A. Needs of Including the Internet in Teaching and Internet Access of School}

All of participants needed to use the Internet in classroom. As Participant 5 explained:

"Sometime I don't have a concrete material in English teaching, so the Internet always use in my class for helping students."

Similarly, Participant 1 sees the effective of the Internet using; in his view, "Of course, I always use the Internet in my classroom. Sometime, no electricity I feel I'm disable I feel I'm not confident to teach only books and whiteboard. In term of technology I think the Internet because I think nowadays everything is on the Internet you can search for knowledge, game, or everything."

In term of the Internet access, some of the individuals believed that their school provided sufficient access to the Internet. [5] noted that access to the Internet and social media develops students' intercultural skills and promotes global awareness.

"My school provides sufficient access to the Internet for teachers and students for using in language learning. There are computers, projectors, smart TV in each class.”(Participant 4)
As Participant 1, he confidently thinks that his school provides enough access to the Internet; In his view, " $M y$ school luckily use in my teaching, but I'm not sure that they provide that to the student as well, because as I say, the students have a chance to use technology in my classroom only. We have computer rooms, but I don't think the computer in that room are good enough for using technology, like slow Internet, old computers. My classroom government supported to build this class." It's known that Thai students reported lower than average computer use in the area of information technology and computer studies. They also experienced above-average obstacles to the use of ICT because their schools reportedly had too few computers connected to the Internet, insufficient Internet bandwidth or speed, insufficient computers for instruction, and unsatisfactory ICT skills among teachers (OECD).

\section{B. Teachers' Confidence to Use Digital Media in the Classroom}

In previous research [6], teachers' confidence in technology improved directly through workshops and technical support, they should be to engage with teaching staff on the pedagogical issues they face and the potential opportunities for solving learning problems and improving learning opportunities for students through experimenting with proven learning technology applications.

However, in term of teachers' confidence of digital educational using in this case, the teachers generally expressed that they were confident to use digital technology in their teaching. As Participant 3 explained:

"I am completely confident with using these materials."

This attitude was supported by Participant 1's contention that 'I'm quite confident to use this technology because I've been using this technology when I was in university. It's quite easy to teach, I think students have fun using technology as well.” as Participant 2 agreed:

"I feel confident about using computer and other digital equipment because it helps me teaching and learning. The students can listen native speakers.”

\section{Administrative Support for Use of Technology in Classroom}

The teachers generally felt that their school administrators encouraged technology use.

"My president fully supports to use technology. When I first came to this school she said you manage this class as you like, look after this class before I came to this school, No one use this classroom." (Participant 1)

"My administrator supports the use of technology in language teaching very much because in my school, there is an Intensive English Program curriculum.” (Participant 4)

However, some participants explained that "My head think it's not important." (Participant 2). 


\section{Digital Technology Using in EFL Classroom}

What principles can teachers follow in selecting and evaluating ICT tools and resources for the EFL classroom? Teachers today may be encouraged or expected by administrators, parents, or learners to incorporate CALL into their teaching. But they may lack familiarity with guidelines on how to do this to the benefit of their learners. Or they may find the number and variety among the tools too great to make sense of. [7] However, the participants can select the digital technology appropriately. The participants' general digital technology using were laptop, computer, smart board, MS PowerPoint, and the Internet. The results seem similar to the results of previous research [2] the most common uses of ICT are the Internet, e-mail, word processing, and educational CDs. As Participant 1 explained;

"Normally, I use a smartboard connected to the Internet in the classroom, but students have no chance to use these technology outside classroom...only in my classroom."

"In my teaching, I always use PC, PowerPoint, and Internet."

There is digital technology using in EFL classroom in general in Thailand. It is well known that ICT use in Thailand's education system began in 1984, when Thai schools began offering computer courses to students in order to provide them with basic skills for operating and applying ICT [1]. Therefore, digital technology has been used for decades.

\section{CONCLUSION}

During the 1980s the main focus of ICT use in education was on the computers themselves and on their basic applications such as word processing, calculation and database management. In time, the concept of information technology grew to also encompass laser discs, CDs and DVDs. With the emergence of the Internet in the mid-1990s the concept of ICT has expanded to include all technologies and applications intended to provide access to information and media and to support communication, such as Internet browsers and e-mail. Finally, the new generation of mobile phones that can access the Internet has further expanded the concept [1].

The results of this study indicate that all of participants needed to use the Internet in the EFL classroom. Due to English language teaching in Thailand is as a foreign language, they have no chance to use an English language outside their classroom. Therefore, the Internet using in language teaching is advantages of their English teaching.

Further, the participants feel confident about digital media using in the classroom. On the other hand, previous study claimed that Thai teachers lack confidence and competence in the use of ICT [1]. Richards (cited in [8]) claimed that "The use of technology in teaching becomes more important in present times, because teachers also have to be able to keep up with the technological knowledge of their students".

Likewise, the teachers generally feel that their school administrators encouraged technology use and the participants' general digital technology using are laptop, computer, smart board, MS PowerPoint, and the Internet.

As [2] stated that some essential equipment to start technology with learners are at least one computer (preferably one per two students), an Internet connection, a printer, an audio card in the computer, and a headset for every computer, and basic software or a web browser like Internet Explorer. In addition to [9] claimed that in the English language classroom in $21^{\text {st }}$ century teachers should provide mobile apps teaching in class. Applications (apps) for use on mobile devices have helped create new uses and functionality for the devices. An apps is a small program for a mobile device that accesses a particular site in a simplified and user-friendly way [7].

Moreover [7] described that for the language teacher today, there is a wide range of digital tools and resources that can extend or expand on language teaching and learning. From free web resources and commercial programs that can help learners practice and develop specific language skills to 'adaptable' programs that can underpin and enable learning to an extent not possible even 20 years ago, teachers and learners have many possible ways to learn with ICT. Language teachers need to be clear about their purpose for incorporating ICT into their classroom. Developing an awareness of how specific tools or techniques can enhance learning is essential.

However, some schools do not provide sufficient access to the Internet. [7] claimed that access to technology is an important first step in the digital conversion of school systems. In Thailand, if schools are to make the best use of rich online curriculum resources, online assessment tools, web-based collaboration systems, digital textbooks and a host of Internet-based technologies such as online computing, they need sufficient broadband bandwidth to facilitate their seamless use in schools [1].

\section{RECOMMENDATION}

The current study was focused on a small group of participant English teaching under similar Primary Educational Service Area Office, and their perspectives are not necessarily representative of Thai English language teachers in general. Therefore, it is recommended that the populations of the next study should be a large group from another Primary Educational Service Area Office. Moreover, a similar study has to be conducted to further validate the result of the present study and to be narrowed down, e.g. digital teaching tools in writing or in speaking.

\section{APPENDIX}

$\underline{\text { Interviewer data }}$

Sex: $\square$ Male $\square$ Female Age:

Educational level: $\square$ Bachelor degree $\square$ Master degree $\square$

Doctoral degree in

Year of English teaching experience years

Interview protocol 
1. What is digital technology in your EFL classroom? (e.g. personal computers, computer software, PowerPoint, videos, and the Internet)

2. What types of language learning programs are available in your school? (e.g. interactive learning software, audio/visual materials, social networking, etc.)

3. How confident do you feel about using computers and other digital equipment in your teaching? Please elaborate.

4. Do you think a need to include Internet and computer in your teaching? Why or why not? If so, which tools do you consider to be the most effective?

5. Do you believe that your school provides sufficient access to the Internet for teachers and students for using in language learning? Please elaborate.

6. Does your school administration encourage/support the use of technology in language teaching? Please explain.

\section{ACKNOWLEDGMENT}

I would like to express my gratitude to Phranakhon Si Ayutthaya Rajabhat University who has supported me in having a chance to join the conference. Finally, it is for my beloved family in Thailand who never stop supporting me.

\section{REFERENCES}

[1] OECD/UNESCO, Education in Thailand: an OECD-UNESCO Perspective, Paris: OECD Publishing, 2016, pp. 250-257.
[2] D. Gavin and H. Nicky, How to Teach English with Technology, Essex: Pearson, 2007, pp. 7-8.

[3] T. Erdogan, "Teachers' effect on ICT Use in Education: the Turkey sample," Procedia Social and Behavioral Sciences, vol. 1, pp. 1285-1294, 2009.

[4] D. S. Solanki et al., "Use of technology in English language teaching and learning: an analysis,” IPEDR, vol. 33, pp. 150-156, 2012.

[5] C. Servet and A. Kubra, "Teachers' views on digital educational tools in English language learning: Benefits and challenges in the Turkish context," The Electronic Journal for English as a Second Language, pp. 1-18, August 2014.

[6] G. Sue and W. Craig, "Developing confidence in the use of digital tools in teaching," The Electronic Journal of e-Learning, vol. 12, pp. 260-267, 2015.

[7] W. Mark, "Language learning with ICT," in English Language Teaching Today: Linking Theory and Practice, R. Willy and W. Handoyo, Ed. Singapore: Springer, pp. 257-276, 2016.

[8] M. Ali, "Using technology in the classroom: A study with Turkish pre-service EFL teachers,” TOJET, vol. 14, issue 2, pp. 229-240, 2015.

[9] E. Jenny, N. Omaima, and R. Preeya, "The Next Generation of Technology: Mobile Apps in English Language Classroom,” IJET, vol. 11, issue 4, pp. 21-27, 2016.

[10] M. Katherine, O’M. Kimberly, R. Roxanne, K. H. Maria, J. John, and B. Katherine, "Teaching in a digital age: How educators use technology to improve student learning," Journal of Research on Technology in Education, vol. 48, no. 3, pp. 194-211, 2016.

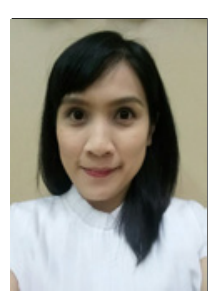

Raksamon Yordming is from Angthong province, Thailand. She was born on April 14, 1986. She earned her master of liberal arts degree in Linguistics for Communication at Thammasat University, Thailand in 2012.

At present, she is an instructor at Teaching English Program, Faculty of Education, Phranakhon Si Ayutthaya Rajabhat University, Thailand. Field of interests is linguistics and language teaching, English phonetics and phonology, educational technologies, and applied linguistics. 